The Canadian Mineralogist

Vol. 38, pp. 641-648 (2000)

\title{
THE CRYSTAL STRUCTURE OF NORMANDITE AND ITS CRYSTAL-CHEMICAL RELATIONSHIPS WITH LÅVENITE
}

\author{
NATALE PERCHIAZZI ${ }^{\S}$ \\ Dipartimento di Scienze della Terra, Università degli Studi di Pisa, Via S. Maria, 53, I-56126 Pisa, Italy \\ ANDREW M. McDONALD \\ Department of Earth Sciences, Laurentian University, Ramsey Lake Road, Sudbury, Ontario P3E 2C6, Canada
}

ROBERT A. GAULT

Research Division, Canadian Museum of Nature, Ottawa, Ontario K1P 6P4, Canada

OLE JOHNSEN

Geological Museum, University of Copenhagen, Oster Voldgade 5-7, DK-1350 Copenhagen, Denmark

STEFANO MERLINO

Dipartimento di Scienze della Terra, Università degli Studi di Pisa, Via S. Maria, 53, I-56126 Pisa, Italy

\begin{abstract}
The crystal structure of normandite from Amdrup Fjord, Greenland and from Mont Saint-Hilaire, Quebec, was solved and refined to a residual $R_{1}$ of 0.033 and 0.047 , respectively. Normandite is a member of the cuspidine group and, more precisely, the $\mathrm{Ca}-\mathrm{Ti}$-dominant analogue of låvenite. Consequently, its structure can be described in terms of "walls" of octahedra, interconnected by corner-sharing and through disilicate groups. These structural "modules" are arranged with the same topology as in cuspidine, hiortdahlite-II, janhaugite and niocalite. EPMA and SEM studies of the Amdrup Fjord material show distinct chemical zoning due to a wide variation of the major elements $\mathrm{Na}, \mathrm{Ca}, \mathrm{Mn}, \mathrm{Zr}$, and $\mathrm{Ti}$, such that a "låvenitic" core gives way to a "normanditic" margin. From these data, the following ideal crystal-chemical formulae are derived: $\mathrm{NaCaMnTiSi}_{2} \mathrm{O}_{7} \mathrm{OF}_{\text {for }}$ normandite and $\mathrm{NaNa} \mathrm{ZrSi}_{2} \mathrm{O}_{7} \mathrm{~F}_{2}(M=\mathrm{Mn}, \mathrm{Fe}, \mathrm{Ca}$, Ti) for låvenite.
\end{abstract}

Keywords: normandite, låvenite, cuspidine group, crystal structure, Zr-Ti zoning.

\section{SOMMAIRE}

Nous avons résolu et affiné la structure cristalline de la normandite provenant du fiord Amdrup, au Gropnland, et du Mont Saint-Hilaire, au Québec, jusqu'à un résidu $R_{1}$ de 0.033 et 0.047 , respectivement. La normandite fait partie du groupe de la cuspidine; plus précisément, il s'agit de l'analogue de la låvenite avec dominance de Ca et de Ti. Par conséquent, on peut décrire sa structure en termes de parois d'octaèdres, liés entre eux par partage de coins et par l'intermédiaire de groupes disilicatés. Ces "modules" structuraux partagent la même topologie que la cuspidine, la hiortdahlite-II, la janhaugite et la niocalite. L'échantillon du fiord Amdrup fait preuve de zonation impliquant une variation importante des éléments majeurs $\mathrm{Na}, \mathrm{Ca}, \mathrm{Mn}, \mathrm{Zr}$, et $\mathrm{Ti}$ (données de microsonde électronique et de microscopie électronique à balayage), de sorte que le noyau est "låvenitique" et la bordure, “normanditique". D'après ces données, nous proposons les formules cristallochimiques idéales suivantes: $\mathrm{NaCaMnTiSi}_{2} \mathrm{O}_{7} \mathrm{OF}$ pour la normandite et $\mathrm{NaNaMZrSi} 2 \mathrm{O}_{7} \mathrm{~F}_{2}(M=\mathrm{Mn}, \mathrm{Fe}, \mathrm{Ca}, \mathrm{Ti})$ pour la låvenite.

(Traduit par la Rédaction)

Mots-clés: normandite, låvenite, groupe de la cuspidine, structure cristalline, zonation Zr-Ti.

§E-mail address: natale@dst.unipi.it, merlino@dst.unipi.it 


\section{INTRODUCTION}

Highly alkaline igneous intrusions such as those found at Mont Saint-Hilaire (Quebec), Kangerdlugssuaq (East Greenland) and the Kola Peninsula (Russia) are characterized by a preponderance of alkali niobo-, titano- and zirconosilicates belonging to the astrophyllite, eudialyte and cuspidine groups. The newest member of the latter group is normandite, with an ideal formula $\mathrm{NaCa}(\mathrm{Mn}, \mathrm{Fe})(\mathrm{Ti}, \mathrm{Nb}, \mathrm{Zr}) \mathrm{Si}_{2} \mathrm{O}_{7} \mathrm{OF}$; it was recently described from the type locality at Mont SaintHilaire, Quebec (Chao \& Gault 1997), and subsequently found at Khibina Massif, Kola Peninsula (Men'shikov et al. 1998). Reports of a phase with similar properties and chemical composition have been noted previously in the literature [e.g., Kola Peninsula: Vlasov (1966), Tenerife, Canary Islands: Ferguson (1978), Tamazeght, Haut Atlas, Morocco: Khadem Allah (1993)]. On the basis of preliminary studies (Chao \& Gault 1997), it was proposed that normandite might form a solid solution with its potential $\mathrm{Zr}$-dominant analogue, låvenite.

During a recent examination of specimens containing the newly recognized eudialyte-group mineral kentbrooksite (Johnsen et al. 1998) from the Kangerdlugssuaq intrusion at Amdrup Fjord, East Greenland, a new occurrence of normandite was identified. A study was initiated to resolve the crystal-structure of the mineral and to investigate its crystal-chemical relationship with låvenite and other members of the cuspidine group. Concurrently, a similar study had been initiated with normandite from Mont Saint-Hilaire. Therefore we decided to join our efforts, and the results are provided herein.

\section{OCCURRENCE}

Normandite and låvenite from Amdrup Fjord are macroscopically indistinguishable, both occurring as yellow-brown crystals, platy on $\{100\}$, elongate on [001], and ranging in length from 0.1 to $1 \mathrm{~cm}$. The mineral occurs with other titano- and zirconosilicates such as catapleiite, eudialyte, hiortdahlite, kentbrooksite and kupletskite in pegmatitic bodies of variable grain-size. The pegmatites are interpreted to have crystallized from late-stage melts injected into already consolidated plutonic rocks (Kempe \& Deer 1970). At Mont SaintHilaire, normandite is found as aggregates of orangebrown, acicular crystals up to $1 \mathrm{~cm}$ in length and as patches of yellow, fibrous crystals occurring both as phenocrysts in nepheline syenite and free-standing crystals in miarolitic cavities in nepheline syenite (Chao \& Gault 1997).

To test for the possible presence of other phases of the cuspidine group in Amdrup Fjord material, seven crystals from two specimens were examined by singlecrystal Weissenberg techniques. As stressed by Merlino \& Perchiazzi (1988), this is the most appropriate technique to unambiguously identify the various mem- bers of this group; moreover, possible twinning, structural disorder, and presence of more than one phase in the same crystal can also be revealed. Such a Weissenberg study indicated the presence of a single låvenitelike phase with cell type I and space-group symmetry $P 2{ }_{1} / a$ (Merlino \& Perchiazzi 1988; see following discussion). A similar study was not performed on the Mont Saint-Hilaire material.

\section{Structure Determination}

The structure of normandite was determined independently using crystals from Amdrup Fjord and Mont Saint-Hilaire. A crystal from Amdrup Fjord was selected from those studied by Weissenberg techniques and mounted on a Siemens four-circle diffractometer. Intensity data were collected under the following operating conditions: $50 \mathrm{kV}$ and $40 \mathrm{~mA}$, graphitemonochromatized MoK $\alpha$ radiation. A $\omega-2 \theta$ scan mode was employed, with a scan width (in $\theta$ ) of $0.8^{\circ}$ and a scan speed of $2 \% \mathrm{~min}$. An absorption correction was performed using the method of North et al. (1968), on the basis of $\Psi$-scan measurements on a set of 15 reflections. The measured intensities were corrected for Lorentz and polarization effects to give a set of 1884 independent squared structure amplitudes $\left(R_{\text {int }}=0.0241\right)$. Information pertinent to the data collection is provided in Table 1.

A crystal from Mont Saint-Hilaire was mounted on a Siemens three-circle diffractometer (University of Notre Dame) equipped with a SMART CCD detector

\section{TABLE 1. CRYSTAL DATA AND REFINEMENT DETAILS FOR NORMANDITE FROM AMDRUP FJORD (AF) AND MONT SAINT HILAIRE (MSH)}

\begin{tabular}{|c|c|c|}
\hline Wavelength: $0.71073 \AA$ & $\mathrm{AF}$ normandite & MSH normandite \\
\hline \multicolumn{3}{|l|}{ Monoclinic, $P_{2} / a$} \\
\hline & \multicolumn{2}{|c|}{ Unit-cell dimensions } \\
\hline$b$ & $9.835(1) \AA$ & $9.801(1) \AA$ \\
\hline$c$ & $7.090(2) \AA$ & $7.054(1) \AA$ \\
\hline$\beta$ & $108.08(3)^{\circ}$ & $108.075(2)^{\circ}$ \\
\hline Crystal size $\quad 0.2$ & $22 \times 0.24 \times 0.08 \mathrm{~mm}$ & $0.06 \times 0.04 \times 0.02 \mathrm{~mm}$ \\
\hline$\theta$ range for data collection & 4 to $60^{\circ}$ & 4 to $56.59^{\circ}$ \\
\hline Index ranges & $\begin{array}{c}-1 \leq h \leq 15 \\
-1 \leq k \leq 13 \\
-9 \leq l \leq 9\end{array}$ & $\begin{array}{c}-14 \leq h \leq 11 \\
-10 \leq k \leq 13 \\
-9 \leq l \leq 9\end{array}$ \\
\hline Reflections collected / unique & $\begin{array}{c}2438 / 1884 \\
{\left[R_{\text {int }}=0.0241\right]}\end{array}$ & $\begin{array}{c}4368 / 1743 \\
{\left[R_{\mathrm{mut}}=0.0611\right]}\end{array}$ \\
\hline Absorption correction & scan on 15 reflections & $\begin{array}{c}\left.\text { Gaussian ( } \mu 24.2 \mathrm{~cm}^{-1}\right) \\
\text { using indexed faces }\end{array}$ \\
\hline Refinement method & \multicolumn{2}{|c|}{ Full-matrix least-squares on $F^{2}$} \\
\hline Data / restraints / parameters & $1884 / 0 / 140$ & $1743 / 0 / 139$ \\
\hline Goodness-of-fit on $F^{2}$ & 1.042 & 1.127 \\
\hline Final $R$ indices ${ }^{a}[I>4 \alpha(I)]$ & $\begin{array}{c}R_{1}=0.0334 \\
w R_{2}=0.0848\end{array}$ & $\begin{array}{c}R_{1}=0.0472 \\
w R_{2}=0.0940\end{array}$ \\
\hline Largest diff. peak and hole & 0.71 and $-1.1 e / \AA^{3}$ & 0.77 and $-0.82 \mathrm{e} / \AA^{3}$ \\
\hline
\end{tabular}

Note: $a$ : Goodness-of-fit $=\left[\Sigma\left[w\left(F_{\mathrm{o}}^{2}-F_{\mathrm{c}}^{2}\right)^{2}\right] /(N-P)\right]^{1 / 2}$, where $N, P$ are the numbers of observations and parameters, respectively, $R_{1}=\Sigma|| F_{\mathrm{o}}|-| F_{\mathrm{c}}|| / \Sigma\left|F_{\mathrm{a}}\right| ; w R_{2}=$ $\left[\Sigma\left[w\left(F_{\mathrm{o}}^{2}-F_{\mathrm{c}}{ }^{2}\right)^{2}\right] / \Sigma\left[w\left(F_{\mathrm{o}}{ }^{2}\right)^{2}\right]\right]^{1 / 5} ; w=1 /\left[\sigma^{2}\left(F_{\mathrm{o}}{ }^{2}\right)+(0.0243 Q)^{2}+0.57 Q\right]$, where $Q$ $=\left[\operatorname{MAX}\left(F_{0}^{2}, 0\right)+2 F_{\mathrm{c}}^{2}\right] / 3$. 
and a crystal-to-detector distance of $5 \mathrm{~cm}$. Intensity data were collected using monochromatic $\mathrm{MoK} \alpha$ radiation and frame widths of $0.2^{\circ}$ in $\omega$, with $30 \mathrm{~s}$ used to acquire each frame. More than a hemisphere of data was collected; the data were then analyzed for peaks used in the determination of unit-cell dimensions. The latter data were subsequently refined by least-squares techniques to produce the values given in Table 1 . The data were reduced and corrected for Lorentz, polarization and background effects using the Siemens program SAINT. Additional information related to the data collection is given in Table 1.

The structure solution using the Amdrup Fjord material employed the atomic coordinates of låvenite (Mellini 1981) as a starting model, including the assumption that the four independent "octahedral" sites are each occupied by $\mathrm{Zr}, \mathrm{Fe}, \mathrm{Ca}$ and $\mathrm{Na}$. Refinement of the structure was carried out using the SHELXL-93 (Sheldrick 1993) program. In five cycles of isotropic refinement, $R$ converged to 0.09 , thus validating the initial structural model. To complete the structure refinement, we took into account the displacement parameters, the peak heights in the Fourier maps, bond lengths and angles, and calculations of bond-valence sums. The latter made it possible to identify the site occupied predominantly by $\mathrm{F}$ and to assess the occupancies of the octahedrally coordinated cations, as reported in Table 2.

The structure of the Mont Saint-Hilaire material was solved through direct methods using the program SHELX-90 (Sheldrick 1990) and refined by means of the SHELXL-93 package (Sheldrick 1993). Scattering curves for neutral atoms and anomalous dispersion corrections were taken from Cromer \& Mann (1968) and Cromer \& Liberman (1970), respectively.

Table 2 includes the final positional coordinates and equivalent isotropic-displacement parameters for normandite from both Mont Saint-Hilaire and Amdrup Fjord.

\section{Description and Discussion of the Structure}

The crystal structure of normandite is represented in Figure 1, in terms of octahedra and tetrahedra (the actual coordination of $\mathrm{Ca}$ cations, which present two additional long bond distances, will be discussed later). The heights in $c / 8$ with respect to the plane normal to the [001] direction and passing through the origin are reported for both the cations and the bridging oxygen atoms of the diorthosilicate groups.

As discussed by Merlino \& Perchiazzi (1988), the crystal structures of minerals belonging to the cuspidine group can be most easily described in terms of two "modules": first, "walls" of edge-sharing octahedra four columns wide and running along $c$, and second, diorthosilicate groups, which are corner-linked to the walls. Each wall is connected by corner-sharing to four other walls, and each $\mathrm{Si}_{2} \mathrm{O}_{7}$ group to three walls. Ten
TABLE 2. FINAL ATOMIC COORDINATES, ISOTROPIC DISPLACEMENT PARAMETERS $\left(\AA^{2}\right)$ AND OCCUPANCIES FOR NORMANDITE

\begin{tabular}{|c|c|c|c|c|c|c|}
\hline & $x$ & $y$ & $z$ & $U_{\text {eq }}$ & \multicolumn{2}{|c|}{ occupancy } \\
\hline \multicolumn{7}{|c|}{ Amdrup Fjord } \\
\hline $\mathrm{Ti}$ & $0.28825(5)$ & $0.10359(4)$ & $0.02313(7)$ & $0.0119(2)$ & $\begin{array}{l}\mathrm{Ti} \\
\mathrm{Zr}\end{array}$ & $\begin{array}{l}0.612(5) \\
0.388\end{array}$ \\
\hline Mn & $0.43743(5)$ & $0.36943(5)$ & $0.85858(8)$ & $0.0139(1)$ & Mn & 1 \\
\hline $\mathrm{Ca}$ & $0.30224(9)$ & $0.10885(8)$ & $0.5255(1)$ & $0.0158(3)$ & $\begin{array}{l}\mathrm{Ca} \\
\mathrm{Na}\end{array}$ & $\begin{array}{l}0.66(1) \\
0.34\end{array}$ \\
\hline $\mathrm{Na}$ & $0.4256(1)$ & $0.3786(1)$ & $0.3398(2)$ & $0.0206(5)$ & $\begin{array}{l}\mathrm{Na} \\
\mathrm{Ca}\end{array}$ & $\begin{array}{l}0.83(1) \\
0.17\end{array}$ \\
\hline Sil & $0.62168(9)$ & $0.16485(9)$ & $0.2136(1)$ & $0.0107(2)$ & & \\
\hline $\mathrm{Si} 2$ & $0.62051(9)$ & $0.16633(9)$ & $0.6705(1)$ & $0.0106(2)$ & & \\
\hline 01 & $0.6397(3)$ & $0.1628(3)$ & $0.4508(4)$ & $0.0246(6)$ & & \\
\hline $\mathrm{O} 2$ & $0.7411(2)$ & $0.2627(2)$ & $0.2050(4)$ & $0.0156(5)$ & & \\
\hline 03 & $0.7480(3)$ & $0.2512(3)$ & $0.8020(4)$ & $0.0166(5)$ & & \\
\hline 04 & $0.6537(3)$ & $0.0111(3)$ & $0.1633(4)$ & $0.0177(5)$ & & \\
\hline 05 & $0.6300(3)$ & $0.0088(3)$ & $0.7400(4)$ & $0.0186(5)$ & & \\
\hline 06 & $0.4784(2)$ & $0.2209(2)$ & $0.0959(4)$ & $0.0145(5)$ & & \\
\hline 07 & $0.4852(3)$ & $0.2392(3)$ & $0.6538(4)$ & $0.0172(5)$ & & \\
\hline 08 & $0.6235(3)$ & $0.4755(3)$ & $0.9577(4)$ & $0.0179(5)$ & & \\
\hline $\mathrm{F}$ & $0.3881(2)$ & $0.5050(2)$ & $0.5998(4)$ & $0.0226(5)$ & & \\
\hline
\end{tabular}

Mont Saint-Hilaire

$\begin{array}{lllllll}\text { Ti } & 0.28342(7) & 0.10168(7) & 0.0210(1) & 0.0054(3) & \mathrm{Ti} & 0.876(5) \\ & & & & \mathrm{Nb} & 0.124 \\ \mathrm{Mn} & 0.43676(7) & 0.36666(8) & 0.85877(11) & 0.00926(23) \mathrm{Mn} & 0.784(2) \\ & & & & \mathrm{Ca} & 0.216 \\ \mathrm{Ca} & 0.300008(10) & 0.10778(12) & 0.52449(16) & 0.00955(41) & \mathrm{Ca} & 0.72(1) \\ & & & & \mathrm{Na} & 0.28 \\ \mathrm{Na} & 0.4243(2) & 0.3781(2) & 0.3372(3) & 0.0089(4) & \mathrm{Na} & 1 \\ \mathrm{Si} 1 & 0.6206(1) & 0.1645(1) & 0.2106(2) & 0.0060(3) & & \\ \mathrm{Si} 2 & 0.6209(1) & 0.1660(1) & 0.6704(2) & 0.0060(3) & & \\ \text { O1 } & 0.6431(3) & 0.1601(4) & 0.4516(5) & 0.0147(8) & \\ \text { O2 } & 0.7395(3) & 0.2647(4) & 0.2014(5) & 0.0102(7) & \\ \text { O3 } & 0.7461(3) & 0.2555(4) & 0.8002(5) & 0.0103(7) & \\ \text { O4 } & 0.6527(3) & 0.0107(4) & 0.1589(5) & 0.0110(7) & & \\ \text { O5 } & 0.6334(3) & 0.0085(4) & 0.7431(5) & 0.0114(7) & & \\ \text { O6 } & 0.4765(3) & 0.2206(4) & 0.0967(5) & 0.0095(7) & & \\ \text { O7 } & 0.4843(3) & 0.2366(4) & 0.6485(5) & 0.0119(8) & & \\ \text { O8 } & 0.6262(3) & 0.4747(4) & 0.9571(5) & 0.0127(8) & & \\ \text { F } & 0.3896(3) & 0.5054(3) & 0.5992(4) & 0.0167(7) & & \\ \end{array}$

topological types exist, corresponding to ten distinct ways in which the silicate groups can be connected to the framework of octahedra, and they can be distributed among four types of unit cells (Table 2 in Merlino \& Perchiazzi 1988).

Normandite, along with cuspidine, låvenite, niocalite, hiortdahlite-II and janhaugite, exhibits cell type I and structure type 1, with topological symmetry $P 2_{1} / a$ (Merlino \& Perchiazzi 1988). The distribution of the cations in the walls of octahedra leads to the different topochemical symmetry (following the terminology of P.B. Moore, in Smith 1970) achieved in each phase. In particular, the topochemical symmetry coincides with the topological one in cuspidine, låvenite and normandite, whereas it is reduced to $P a$ in niocalite, and to $P \overline{1}$ in hiortdahlite-II; in janhaugite, the ordering of the cations results in a doubling of the $c$ parameter and in a space-group symmetry $P 2_{1} / n$.

With the exception of cuspidine, which contains only calcium cations in the walls of octahedra, all the abovementioned minerals have in the outer columns of 


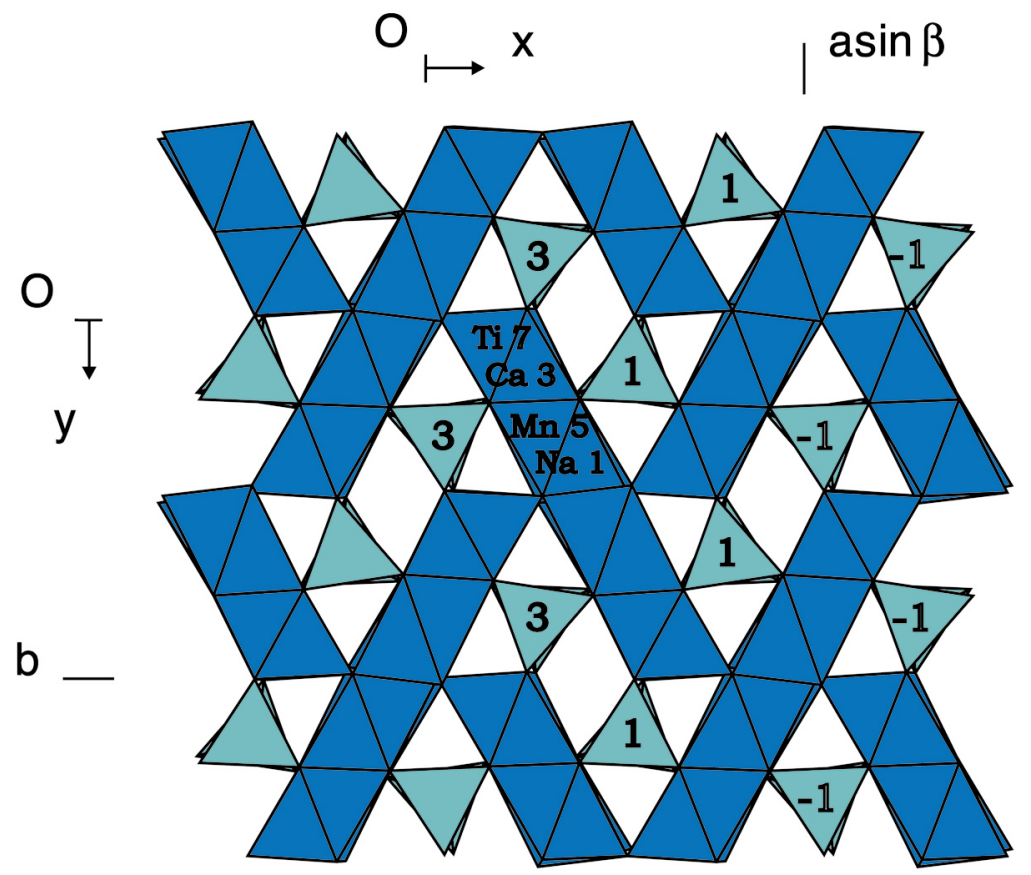

FIG. 1. The crystal structure of normandite as seen along [001]. The connections between the diorthosilicate groups and the octahedra are given by the heights of both the "octahedral" cations and the bridging oxygen of $\mathrm{Si}_{2} \mathrm{O}_{7}$ groups. These heights are given in $c / 8$, with respect to the plane normal to the [001] direction and passing through the origin.

the walls an alternation along [001] of large polyhedra, with disilicate groups linked on both sides, and "free" polyhedra, hosting small-radius high-charge cations. Figure 2 illustrates the wall of octahedra in the structure of normandite; the outer columns present the alterna-

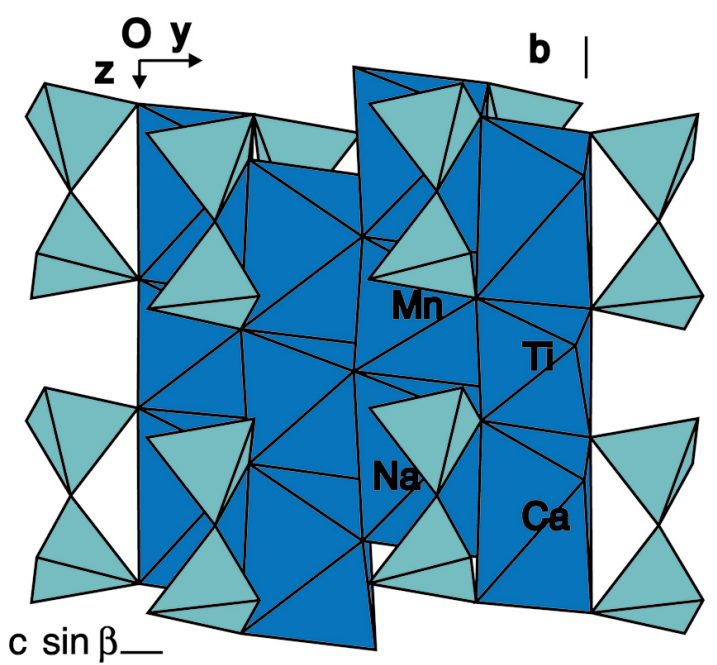

FIG. 2. The crystal structure of normandite as seen along [100]. tion of Ca sites (with disilicate groups bridged on both sides of the corresponding polyhedron) and Ti sites; in the inner columns of octahedra $\mathrm{Mn}$ and $\mathrm{Na}$ sites alternate regularly.

In a structural study of a synthetic Lu-doped cuspidine, $\mathrm{NaCa}_{2} \mathrm{LuSi}_{2} \mathrm{O}_{7} \mathrm{~F}_{2}$, Fleet \& Pan (1995) emphasized its relationships with the other phases of the cuspidine group, and described the cation distribution in the walls of octahedra. In the inner columns of the walls, $\mathrm{Ca}(1)$ and $\mathrm{Ca}(2)$, with occupancies $\mathrm{Na}_{0.845} \mathrm{Ca}_{0.155}$ and $\mathrm{Ca}_{0.845} \mathrm{Na}_{0.155}$, respectively, regularly alternate along $c$. The Lu cations are hosted in the $\mathrm{Ca}(3)$ and $\mathrm{Ca}(4)$ sites, which regularly alternate along $c$ in the outer columns of the walls, with occupancies $\mathrm{Lu}_{0.845} \mathrm{Ca}_{0.155}$ and $\mathrm{Ca}_{0.845} \mathrm{Lu}_{0.155}$, respectively. The $\mathrm{Ca}(4)$ polyhedron exhibits disilicate groups linked on both sites, whereas $\mathrm{Ca}(3)$, in which $\mathrm{Lu}$ is the dominant cation, is "free", therefore adopting the same structural scheme as in låvenite and normandite.

Fleet \& Pan (1995) maintained that the rare earths can be accommodated in the cuspidine structure according to the substitution $\mathrm{Ca}^{2+}=\mathrm{Na}^{+}+R E E^{3+}$, which, however, is limited in extent to the composition $\mathrm{NaCa}_{2}$ REESi ${ }_{2} \mathrm{O}_{7} \mathrm{~F}_{2}$. Moreover, they discussed another possible extensive substitution, $\mathrm{Ca}^{2+}+\mathrm{Si}^{4+}=\mathrm{Na}^{+}+\mathrm{P}^{5+}$, which would lead to the end member $\mathrm{Na}_{2} \mathrm{Ca}_{2}\left(\mathrm{P}_{2} \mathrm{O}_{7}\right) \mathrm{F}_{2}$. This compound has been recently synthesized by 
TABLE 3. BOND DISTANCES AND ANGLES OF THE DIORTHOSILICATE GROUPS $\left(\AA,{ }^{\circ}\right)$ IN NORMANDITE FROM AMDRUP FJORD (AF) AND MONT SAINT HILAIRE (MSH)

\begin{tabular}{|c|c|c|c|c|c|c|c|c|c|}
\hline & & $\mathrm{AF}$ & MSH & & $\mathrm{AF}$ & MSH & & $\mathrm{AF}$ & MSH \\
\hline \multirow[t]{5}{*}{ Sil } & -01 & $1.632(3)$ & $1.641(4)$ & $\mathrm{O} 1-\mathrm{O} 2$ & $2.527(5)$ & $2.528(6)$ & $\mathrm{O} 1-\mathrm{Sil}-\mathrm{O} 2$ & $101.8(1)$ & $101.0(2)$ \\
\hline & $-\mathrm{O} 2$ & $1.626(3)$ & $1.634(4)$ & $\mathrm{Ol}-\mathrm{O} 4$ & $2.568(4)$ & $2.559(5)$ & $\mathrm{O} 1-\mathrm{Sil}-\mathrm{O} 4$ & $104.5(1)$ & $103.7(2)$ \\
\hline & -04 & $1.616(3)$ & $1613(4)$ & $01-06$ & $2.641(3)$ & $2.657(4)$ & $\mathrm{O} 1-\mathrm{Sil}-\mathrm{O} 6$ & $109.1(1)$ & $109.6(2)$ \\
\hline & -06 & $1.610(3)$ & $1.610(3)$ & $\mathrm{O} 2-\mathrm{O} 4$ & $2.632(3)$ & $2.644(5)$ & $\mathrm{O} 2-\mathrm{Sil}-\mathrm{O} 4$ & $108.6(1)$ & $109.0(2)$ \\
\hline & & & & $\mathrm{O} 2-\mathrm{O} 6$ & $2.723(3)$ & $2.738(5)$ & $\mathrm{O} 2-\mathrm{Sil}-\mathrm{O} 6$ & $115.0(1)$ & $115.1(2)$ \\
\hline \multicolumn{2}{|c|}{ Average } & 1.621 & 1624 & $04-06$ & $2.740(4)$ & $2.743(5)$ & O4-Si1 - O6 & $116.3(1)$ & $116.6(2)$ \\
\hline \multirow[t]{5}{*}{$\mathrm{Si} 2$} & \multicolumn{2}{|c|}{$-011.635(3)$} & $1.635(4)$ & $\mathrm{O} 1-\mathrm{O} 3$ & $2.553(4)$ & $2.542(5)$ & $\mathrm{O} 1-\mathrm{Si} 2-\mathrm{O} 3$ & $102.8(1)$ & $102.1(2)$ \\
\hline & -03 & $1.633(3)$ & $1.633(4)$ & $01 \cdot 05$ & $2.578(4)$ & $2566(5)$ & $\mathrm{O} 1-\mathrm{Si} 2-\mathrm{O} 5$ & $1048(1)$ & $104.1(2)$ \\
\hline & -05 & $1.619(3)$ & $1.619(4)$ & $01-07$ & $2.629(5)$ & $2.629(5)$ & $\mathrm{Ol}-\mathrm{Si2}-\mathrm{O} 7$ & $108.8(1)$ & $109.0(2)$ \\
\hline & -07 & $1.599(3)$ & $1.593(4)$ & $03-05$ & $2.675(4)$ & $2.683(5)$ & $\mathrm{O} 3-\mathrm{Si2}-\mathrm{O} 5$ & $110.7(1)$ & $111.2(2)$ \\
\hline & & & & $03-07$ & $2.706(4)$ & $2.701(5)$ & $\mathrm{O} 3-\mathrm{Si}-\mathrm{O} 7$ & $113.7(1)$ & $113.7(2)$ \\
\hline \multicolumn{2}{|c|}{ Average } & 1.621 & 1.620 & $05-07$ & $2.713(4)$ & $2.714(5)$ & $\mathrm{OS}-\mathrm{Si2}-\mathrm{O} 7$ & $114.9(1)$ & $115.4(2)$ \\
\hline \multicolumn{2}{|c|}{$\mathbf{S i} 1-\mathbf{S i} 2$} & $3.243(2)$ & $3.242(2)$ & & & & $\mathrm{Si1}-\mathrm{O} 1-\mathrm{Si} 2$ & $166.4(2)$ & $163.5(2)$ \\
\hline
\end{tabular}

Piotrowski et al. (1999), who showed that it is a member of the cuspidine group. Whereas cuspidine, låvenite, niocalite, hiortdahlite-II, janhaugite, normandite and Lu-doped cuspidine adopt structure type 1 of Merlino \& Perchiazzi (1988), $\mathrm{Na}_{2} \mathrm{Ca}_{2}\left(\mathrm{P}_{2} \mathrm{O}_{7}\right) \mathrm{F}_{2}$ displays the structure type 5 , which confirms the soundness and usefulness of that classification scheme.

\section{Structural details}

Diorthosilicate groups. Bond distances and angles for the diorthosilicate groups present in normandite are given in Table 3. Average and individual distances are very close for normandite from the two localities. In normandite from Mont Saint-Hilaire, individual distances vary from $1.593 \AA$ (for Si2-O7, the bond with the only oxygen atom not linked to the Ti site) to $1.641 \AA$ (for the Si1-O1 bridging bond), whereas in normandite from Amdrup Fjord, the extreme values were found for Si2-O7, $1.599 \AA$, and Si2-O1 bridging bond, 1.641 A. The $\mathrm{Si}-\mathrm{O}-\mathrm{Si}$ angles vary from $163.5^{\circ}$ in normandite from Mont Saint-Hilaire to $166.4^{\circ}$ in normandite from Amdrup Fjord. These are close to the value of $171^{\circ}$ observed in låvenite (Mellini 1981). Relative to låvenite, the smaller $\mathrm{Si}-\mathrm{O}-\mathrm{Si}$ angles in normandite are related to their higher $\Delta \mathrm{d}$ values [difference between the averages of the bridging and non-bridging bond-lengths: Louisnathan \& Smith (1970), O'Keeffe \& Hyde (1978)].

Low values of $\Delta \mathrm{d}$ are due to the presence of short $\mathrm{Si}-\mathrm{O}(\mathrm{br})$ bonds, which leads to charge oversaturation of the bridging oxygen atom, which in turn can only weakly bond to any associated octahedrally coordinated cation. In låvenite, with $\Delta \mathrm{d}=0.002 \AA$ and $\mathrm{Si}-\mathrm{O}-\mathrm{Si}$ angle of $171^{\circ}, \mathrm{O}(\mathrm{br})$ is weakly bonded to the cations in $\mathrm{Na}$ site, at distances of 2.835 and $2.840 \AA$. The smaller $\mathrm{Si}-\mathrm{O}-\mathrm{Si}$ angles in normandite from Amdrup Fjord, $166.4^{\circ}$ and from Mont Saint-Hilaire, $163.5^{\circ}$, relate well with their higher $\Delta \mathrm{d}$ values: $0.016 \AA$ in normandite from Amdrup Fjord (and two weak bonds, 2.737 and
$2.798 \AA$, to Ca), and $0.021 \AA$ in normandite from Mont Saint-Hilaire (and two weak bonds, 2.688 and $2.792 \AA$, to $\mathrm{Ca}$ ), respectively.

Bond-valence calculations, reported in Table 4, indicate that in normandite, as in all the other phases of the cuspidine group, $\mathrm{O}(\mathrm{br})$ is overbonded. This aspect has been already discussed by Mellini (1981), who maintained that the systematic overbonding of the $\mathrm{O}(\mathrm{br})$

TABLE 4. BOND-VALENCE SUMS ( $v u$ ), CALCULATED ON THE BASIS OF SITE OCCUPANCIES DERIVED FROM STRUCTURAL DATA FOR NORMANDITE FROM AMDRUP FJORD (AF) AND MONT SAINT HILAIRE (MSH)

\begin{tabular}{|c|c|c|c|c|c|c|c|}
\hline MSH & $\mathrm{Ti}$ & $\mathrm{Mn}$ & $\mathrm{Ca}$ & $\mathrm{Na}$ & Si1 & $\mathrm{Si} 2$ & $\Sigma_{a} v$ \\
\hline $\mathrm{O} 1$ & & & $\begin{array}{l}0.128 \\
0.097\end{array}$ & & 0.955 & 0.971 & 2.151 \\
\hline $\mathrm{O} 2$ & 0.657 & & 0.212 & 0.208 & 0.973 & & 2.050 \\
\hline $\mathrm{O} 3$ & 0.566 & 0.282 & 0.173 & & & 0.976 & 1.997 \\
\hline $\mathrm{O} 4$ & 0.701 & & 0.259 & & 1.030 & & 1.990 \\
\hline O5 & 0.715 & & 0.218 & & & 1.014 & 1.947 \\
\hline O6 & 0.277 & 0.434 & & 0.157 & 1.039 & & 1.907 \\
\hline 07 & & 0.445 & 0.383 & 0.148 & & 1.087 & 2.063 \\
\hline O8 & 1.136 & $\begin{array}{l}0.358 \\
0.316\end{array}$ & & 0.174 & & & 1.984 \\
\hline F & & 0.277 & 0.333 & $\begin{array}{l}0.223 \\
0.160\end{array}$ & & & 0.993 \\
\hline$\Sigma_{\mathrm{c}} y$ & 4.052 & 2.112 & 1.803 & 1.070 & 3.997 & 4.048 & \\
\hline $\mathrm{AF}$ & $\mathrm{Ti}$ & $\mathrm{Mn}$ & $\mathrm{Ca}$ & $\mathrm{Na}$ & $\mathrm{Sil}$ & $\mathrm{Si} 2$ & $\Sigma_{\mathbf{a}} v$ \\
\hline 01 & & & $\begin{array}{l}0.109 \\
0.092\end{array}$ & & 0.979 & 0.971 & 2.151 \\
\hline $\mathrm{O} 2$ & 0.672 & & 0.207 & 0.233 & 0.995 & & 2.107 \\
\hline $\mathrm{O} 3$ & 0.587 & 0.259 & 0.155 & & & 0.976 & 1.977 \\
\hline $\mathrm{O} 4$ & 0.735 & & 0.260 & & 1.022 & & 2.082 \\
\hline O5 & 0.747 & & 0.204 & & & 1.014 & 1.965 \\
\hline O6 & 0.336 & 0.361 & & 0.158 & 1.039 & & 1.894 \\
\hline 07 & & 0.414 & 0.362 & 0.155 & & 1.070 & 2.001 \\
\hline O8 & 1.011 & $\begin{array}{l}0.350 \\
0.301\end{array}$ & & 0.179 & & & 1.841 \\
\hline $\mathrm{F}$ & & 0.260 & 0.316 & $\begin{array}{l}0.241 \\
0.172\end{array}$ & & & 0.989 \\
\hline$\Sigma_{c} v$ & 4.088 & 1.945 & 1.705 & 1.140 & 4.035 & 4.031 & \\
\hline
\end{tabular}


anions may be "due to the use of a correlation between bond distance and bond strength which does not take account of other parameters, like bond angles, mutual screening among anions and so on." In the cases here discussed, the bridging oxygen atom of the diorthosilicate group is actually screened by the non-bridging oxygen atoms, and it is conceivable that this results in a weaker interaction with $\mathrm{Ca}$ than expected on the basis of the measured distance.

Walls of octahedra. Bond distances for the four independent cation sites are given in Table 5. The $\mathrm{TiO}_{6}$ octahedron is defined by five oxygen atoms belonging to the diorthosilicate groups and by one "free" O8 oxygen, the latter forming the shortest $\mathrm{Ti}-\mathrm{O}$ bond in the octahedron.

As may be seen in Table 5, a pattern with one long and five short bonds is present both in normandite from Amdrup Fjord (mean short distance $1.979 \AA$ A, long distance $2.271 \AA$ ) and from Mont Saint-Hilaire (mean short distance $1.943 \AA$, long distance $2.303 \AA$ ). In fact, as discussed by Megaw (1968a, b), small cations with high charge, like niobium and titanium, may give rise to off-center displacement. The definitely higher titanium content of the $T i$ site in normandite from Mont Saint-Hilaire, relative to that from Amdrup Fjord, explains both the shorter mean $\mathrm{Ti}-\mathrm{O}$ distance and the larger off-center displacement in the corresponding $\mathrm{TiO}_{6}$ octahedron. The $\mathrm{TiO}_{6}$ octahedron in normandite is quite similar to that in janhaugite (Annehed et al. 1985), both in terms of bond distances and extent of offcenter displacement. In fact, the two independent Ti sites in janhaugite, Ti1 and Ti2, with cation occupancies $\mathrm{Ti}_{0.67} \mathrm{Zr}_{0.33}$ and $\mathrm{Ti}_{0.73} \mathrm{Zr}_{0.27}$, respectively, have mean Ti-O bond lengths of 2.014 and $2.010 \AA$, respectively, TABLE 5. BOND DISTANCES $(\AA)$ IN LARGE CATION POLYHEDRA
IN NORMANDITE

FROM AMDRUP FJORD (AF) AND MONT SAINT-HILAIRE (MSH)

\begin{tabular}{|c|c|c|c|c|c|c|}
\hline & & $\mathrm{AF}$ & MSH & & $\mathrm{AF}$ & MSH \\
\hline \multirow[t]{6}{*}{$\mathrm{Ti}-$} & $08^{i}$ & $1.863(3)$ & $1.781(3)$ & $\mathrm{Mn}-\mathrm{O} 7$ & $2.116(3)$ & $2.136(4)$ \\
\hline & $05^{\mathfrak{a}}$ & $1.975(3)$ & $1.953(3)$ & $06^{v}$ & $2.167(3)$ & $2.145(4)$ \\
\hline & $\mathrm{O} 4^{\mathrm{iii}}$ & $1.981(3)$ & $1,960(3)$ & 08 & $2.178(3)$ & $2.216(4)$ \\
\hline & $\mathrm{O} 2^{\mathrm{w}}$ & $2.014(3)$ & $1.984(3)$ & $\mathrm{F}$ & $2.196(3)$ & $2.210(4)$ \\
\hline & $\mathrm{O}^{\mathrm{i}}$ & $2.064(3)$ & $2.039(3)$ & $08^{\mathrm{i}}$ & $2.234(3)$ & $2.262(5)$ \\
\hline & 06 & $2.271(3)$ & $2.303(3)$ & $\mathrm{O} 3^{\mathrm{i}}$ & $2.290(3)$ & $2.305(3)$ \\
\hline \multicolumn{2}{|c|}{ mean } & 2.028 & 2.003 & mean & 2.197 & 2.212 \\
\hline \multirow[t]{6}{*}{$\mathrm{Ca}-$} & $F^{\mathrm{vi}}$ & $2.219(2)$ & $2.203(2)$ & $\mathrm{Na}-\mathrm{F}^{\mathrm{wi}}$ & $2.237(3)$ & $2.233(3)$ \\
\hline & 07 & $2.293(3)$ & $2.289(3)$ & $\mathrm{F}$ & $2.360(3)$ & $2.354(3)$ \\
\hline & $\mathrm{O} 4^{\mathrm{i}}$ & $2.416(3)$ & $2.428(4)$ & $\mathrm{O} 2^{\mathrm{vy}}$ & $2.373(3)$ & $2.381(4)$ \\
\hline & $\mathrm{O} 2^{\mathrm{iv}}$ & $2.502(3)$ & $2.502(3)$ & $08^{\text {vi }}$ & $2.468(3$ & $2.446(4)$ \\
\hline & $05^{i i}$ & $2.505(3)$ & $2.490(4)$ & O6 & $2.517(3)$ & $2.485(4)$ \\
\hline & $\mathrm{O}^{\mathrm{tv}}$ & $2.607(3)$ & $2.573(4)$ & 07 & $2.522(3)$ & $2.506(4)$ \\
\hline \multirow[t]{3}{*}{ mean } & & 2.423 & 2.414 & mean & 2.413 & 2.401 \\
\hline & $\mathrm{Ol}^{\mathrm{H}}$ & $2.737(3)$ & $2.688(4)$ & & & \\
\hline & $\mathrm{O} 1^{\mathrm{in}}$ & $2.798(3)$ & $2.788(4)$ & & & \\
\hline
\end{tabular}

\begin{tabular}{lccclccc}
\hline i atom at & $x-1 / 2$ & $1 / 2-y$ & $z-1$ & v atom at & $x$ & $y$ & $z+1$ \\
ii atom at & $1-x$ & $-y$ & $1-z$ & vi atom at & $1-x$ & $1-y$ & $2-z$ \\
iii atom at & $1-x$ & $-y$ & $-z$ & vii atom at & $1 / 2-x$ & $y-1 / 2$ & $1-z$ \\
iv atom at & $1 / 2-x$ & $1 / 2-y$ & $z$ & viii atom at & $1-x$ & $1-y$ & $1-z$
\end{tabular}

and differences between the long distance and the mean short distance of $0.25 \AA$ and $0.31 \AA$, respectively. In låvenite, the $Z r$ polyhedron, occupied by $Z r$ with very minor niobium, displays a larger mean bond-distance $(2.083 \AA$ ) and a smaller off-center displacement (mean short distance $2.117 \AA$, long distance $2.224 \AA$ ).

The $\mathrm{MnO}_{6}$ octahedron is distorted, with a pattern of bond distances ranging from a minimum for $\mathrm{Mn}-\mathrm{O} 7$ $(2.116 \AA$ in Amdrup Fjord normandite and $2.136 \AA$ in Mont Saint-Hilaire normandite) to a maximum for Mn-O3 (2.290 A in Amdrup Fjord normandite and $2.305 \AA$ in Mont Saint-Hilaire normandite). A similar pattern of bond distribution is presented by Mn octahedra in janhaugite, as well as by the Fe octahedron in

TABLE 6. SELECTED CHEMICAL DATA FOR NORMANDITE AND LÅVENITE FROM MONT SAINT HILAIRE AND AMDRUP FJORD

\begin{tabular}{|c|c|c|c|c|c|c|c|c|c|}
\hline & MSHN & MSHL & 1 & 2 & 3 & 4 & 5 & 6 & 7 \\
\hline $\mathrm{Na}_{2} \mathrm{O} w t \%$ & 9.26 & 11.20 & 9.78 & 10.73 & 10.40 & 11.85 & 12.20 & 12.37 & 12.63 \\
\hline $\mathrm{CaO}$ & 15.38 & 6.94 & 12.63 & 10.74 & 10.42 & 8.97 & 8.59 & 8.45 & 8.06 \\
\hline SrO & n.d. & n.d. & 0.04 & 0.06 & 0.05 & 0.13 & 0.14 & 0.15 & 0.11 \\
\hline $\mathrm{MgO}$ & n.d. & 0.15 & 0.25 & 0.23 & 0.21 & 0.21 & 0.24 & 0.25 & 0.25 \\
\hline $\mathrm{MnO}$ & 9.31 & 10.38 & 14.76 & 14.32 & 13.21 & 10.13 & 9.02 & 8.42 & 8.70 \\
\hline $\mathrm{FeO}$ & 6.13 & 2.39 & 2.77 & 2.36 & 2.13 & 2.54 & 2.62 & 3.16 & 3.13 \\
\hline $\mathrm{Al}_{2} \mathrm{O}_{3}$ & n.d. & 0.04 & n.d. & 0.05 & n.d. & n.d. & n.d. & n.d. & n.d. \\
\hline $\mathrm{Y}_{2} \mathrm{O}_{3}$ & n.d. & n.d. & n.d. & 0.14 & 0.20 & 0.28 & 0.20 & 0.27 & 0.26 \\
\hline $\mathrm{Ce}_{2} \mathrm{O}_{3}$ & n.d. & n.d. & n.d. & n.d. & n.d. & 0.14 & 0.18 & n.d. & 0.16 \\
\hline $\mathrm{TiO}_{2}$ & 17.51 & 1.81 & 17.43 & 13.20 & 11.84 & 7.52 & 6.19 & 6.10 & 5.72 \\
\hline $\mathrm{ZrO}_{2}$ & 2.62 & 26.18 & 5.58 & 9.66 & 11.84 & 19.29 & 22.14 & 22.17 & 22.42 \\
\hline $\mathrm{HfO}_{2}$ & n.d. & n.d. & 0.56 & 0.72 & 0.79 & 1.09 & 1.24 & 1.13 & 1.12 \\
\hline $\mathrm{Nb}_{2} \mathrm{O}_{5}$ & 3.89 & 7.63 & 1.52 & 3.52 & 3.79 & 4.05 & 3.99 & 4.05 & 4.25 \\
\hline $\mathrm{Ta}_{2} \mathrm{O}_{5}$ & n.d. & n.d. & 0.03 & 0.13 & 0.05 & 0.10 & 0.07 & 0.13 & 0.06 \\
\hline $\mathrm{SiO}_{2}$ & 31.92 & 29.05 & 31.05 & 30.92 & 30.09 & 30.11 & 29.37 & 29.77 & 29.91 \\
\hline $\mathrm{F}$ & 5.11 & 3.71 & 4.79 & 5.27 & 5.04 & 5.59 & 5.66 & 5.29 & 5.63 \\
\hline$-\mathrm{O}=\mathrm{F}$ & 2.15 & 1.56 & 2.02 & 2.22 & 2.12 & 2.35 & 2.38 & 2.23 & 2.37 \\
\hline sum & 98.99 & 98.36 & 99.17 & 99.83 & 97.94 & 99.65 & 99.47 & 99.48 & 100.04 \\
\hline $\mathrm{Na}^{+}$apfu & 1.125 & 1.485 & 1.205 & 1.332 & 1.325 & 1.51 & 1.572 & 1.593 & 1.617 \\
\hline $\mathrm{Ca}^{2+}$ & 1.03 & 0.51 & 0.86 & 0.737 & 0.733 & 0.632 & 0.612 & 0.601 & 0.570 \\
\hline$\Sigma$ & 2.155 & 1.995 & 2.065 & 2.069 & 2.058 & 2.142 & 2.184 & 2.194 & 2.187 \\
\hline $\mathrm{Sr}^{2+}$ & 0 & 0 & 0.001 & 0.002 & 0.002 & 0.005 & 0.005 & 0.006 & 0.004 \\
\hline $\mathrm{Mg}^{2+}$ & 0 & 0.015 & 0.024 & 0.022 & 0.021 & 0.021 & 0.024 & 0.025 & 0.025 \\
\hline $\mathrm{Mn}^{2+}$ & 0.495 & 0.6 & 0.795 & 0.777 & 0.735 & 0.564 & 0.508 & 0.474 & 0.487 \\
\hline $\mathrm{Fe}^{2+}$ & 0.32 & 0.135 & 0.147 & 0.126 & 0.117 & 0.14 & 0.146 & 0.176 & 0.173 \\
\hline$\Sigma$ & 0.815 & 0.75 & 0.967 & 0.927 & 0.875 & 0.73 & 0.683 & 0.681 & 0.689 \\
\hline $\mathrm{Al}^{3+}$ & 0 & 0.005 & 0 & 0.004 & 0 & 0 & 0 & 0 & 0 \\
\hline $\mathrm{Y}^{3+}$ & 0 & 0 & 0 & 0.005 & 0.007 & 0.01 & 0.007 & 0.01 & 0.009 \\
\hline $\mathrm{Ce}^{3+}$ & 0 & 0 & 0 & 0 & 0 & 0.003 & 0.004 & 0 & 0.004 \\
\hline $\mathrm{Ti}^{4+}$ & 0.825 & 0.095 & 0.833 & 0.636 & 0.585 & 0.372 & 0.309 & 0.305 & 0.284 \\
\hline $\mathrm{Zr}^{4+}$ & 0.08 & 0.87 & 0.173 & 0.302 & 0.379 & 0.618 & 0.718 & 0.718 & 0.722 \\
\hline $\mathrm{Hf}^{4+}$ & 0 & 0 & 0.01 & 0.013 & 0.015 & 0.02 & 0.024 & 0.021 & 0.021 \\
\hline $\mathrm{Nb}^{5+}$ & 0.11 & 0.235 & 0.044 & 0.102 & 0.113 & 0.12 & 0.12 & 0.122 & 0.127 \\
\hline $\mathrm{Ta}^{5+}$ & 0 & 0 & 0.001 & 0.002 & 0.001 & 0.002 & 0.001 & 0.002 & 0.001 \\
\hline$\Sigma$ & 1.015 & 1.205 & 1.061 & 1.064 & 1.1 & 1.145 & 1.183 & 1.178 & 1.168 \\
\hline $\mathrm{Si}^{4+}$ & 2 & 1.985 & 1.973 & 1.98 & 1.977 & 1.979 & 1.952 & 1.977 & 1.975 \\
\hline$\Sigma_{\text {cations }}$ & 5.985 & 5.935 & 6.066 & 6.041 & 6.009 & 5.995 & 6.001 & 6.029 & 6.020 \\
\hline $\mathbf{F}^{-}$ & 1.01 & 0.8 & 0.963 & 1.068 & 1.047 & 1.162 & 1.19 & 1.111 & 1.176 \\
\hline $\mathrm{O}^{2-}$ & 7.99 & 8.2 & 8.037 & 7.932 & 7.953 & 7.838 & 7.81 & 7.889 & 7.824 \\
\hline
\end{tabular}

Crystal-chemical formulae, expressed in atoms per formula unit (apfu), recalculated on the basis of $(O+F)=9$, for normandite and låvenite from Mont Saint Hilaire (MSHN and MSHL), from Chao \& Gault (1997) and Amdrup Fjord (1-7, present work). The composition in column 2 pertains to chemically homogeneous crystal fragment of normandite from Amdrup Fjord used in the determination of the structure. 


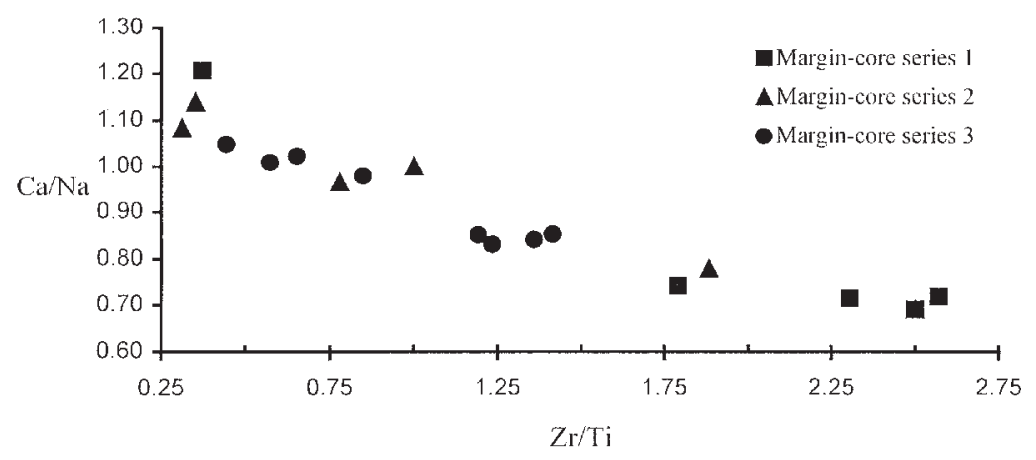

FIG. 3. Ca/Na versus $\mathrm{Zr} / \mathrm{Ti}$ trend in normandite from Amdrup Fjord.

låvenite. In all cases, the distortion of the octahedra is dictated by the requirements of balance in bond valence.

As regards $\mathrm{Ca}$ and $\mathrm{Na}$ sites, the first is dominantly occupied by calcium (occupancies $\mathrm{Ca}_{0.66} \mathrm{Na}_{0.34}$ and $\mathrm{Ca}_{0.72} \mathrm{Na}_{0.28}$ in Amdrup Fjord and Mont Saint-Hilaire material, respectively), the second is exclusively or dominantly occupied by sodium (occupancies $\mathrm{Na}_{0.83} \mathrm{Ca}_{0.17}$ and $\mathrm{Na}_{1.00}$ in Amdrup Fjord and Mont Saint-Hilaire material, respectively). The $\mathrm{Na}$ site is octahedrally coordinated, whereas the $\mathrm{Ca}$ site shows a $6+2$ coordination, with six ligands forming an octahedral coordination with a mean bond-distance of $2.42 \AA$ and two additional, more distant ligands, corresponding to the two $\mathrm{O}$ (br) of the $\mathrm{Si}_{2} \mathrm{O}_{7}$ groups chelating this polyhedron on both sides. Wherever this last situation occurs in other members of the cuspidine group, the same $6+2$ coordination is present.

\section{Crystal chemistry of normandite and låvenite}

Compositional data for låvenite and normandite from Mont Saint-Hilaire and Amdrup Fjord were obtained by electron-probe micro-analysis (EPMA) and are reported in Table 6. A detailed set of chemical data for låvenite was given in Mellini (1981).

A wide variation in composition can be noticed both in the data of Table 6 and in those of Table 2 of Mellini (1981). This is not surprising, if we consider the large variety of octahedrally coordinated cations that are found in the various members of the cuspidine group. Recorded in Table 6 are some remarkable peculiarities in the crystal chemistry of normandite. In fact, the $\mathrm{Na}$ and $\mathrm{Ca}$ cations filling the "mixed" $\mathrm{Na}$ and $\mathrm{Ca}$ site are always in excess with respect to the expected value of 2 atoms per formula unit, apfu, with the exception of låvenite from Mont Saint-Hilaire.

In this set of data, two distinct antithetic trends are present for $\mathrm{Na}$ and $\mathrm{Ca}$; in going from "normanditic" to "låvenitic" compositions, the occupancy by $\mathrm{Na}$ increases, together with the amount of cations in excess. A constant excess is present also for the high-charge cations, hosted in the $(\mathrm{Ti}, \mathrm{Zr})$ site. As regards the $M n$ site, it is always underpopulated, and the occupancy by $\mathrm{Mn}$ and Fe clearly decreases from normandite to låvenite: as the $\mathrm{Fe}$ content is practically constant, the drop in the occupancy is related to the Mn content. These considerations clearly point to a scheme in which the full occupancy in the Mn site is restored by the cations in excess in the $\mathrm{Na}, \mathrm{Ca}$ and $\mathrm{Ti}$ structural sites, namely major $\mathrm{Ca}$ and some $\mathrm{Ti}$.

These natural phases could therefore be considered as intermediates in a series with end members having the ideal formulae $\mathrm{NaCaMnTiSi}{ }_{2} \mathrm{O}_{7} \mathrm{OF}$, corresponding to normandite, and $\mathrm{NaNa} M \mathrm{ZrSi}_{2} \mathrm{O}_{7} \mathrm{~F}_{2}$ (where $M$ is a mixed site hosting major $\mathrm{Mn}$ with $\mathrm{Fe}, \mathrm{Ca}, \mathrm{Ti}$ ), corresponding to låvenite.

In Figure 3 and Table 7, the results of a semiquantitative analysis by energy-dispersion spectrometry

TABLE 7. CORE-TO-MARGIN TRENDS OF SELECTED CATIONS FOR NORMANDITE AND LÅVENITE FROM AMDRUP FJORD

\begin{tabular}{|c|c|c|c|c|c|}
\hline \multicolumn{6}{|c|}{ Series 1} \\
\hline Normandite & core & & & & margin \\
\hline $\mathrm{Zr} / \mathrm{Ti}$ & 2.50 & 2.57 & 2.30 & 1.79 & 0.37 \\
\hline $\mathrm{Ca} / \mathrm{Na}$ & 0.69 & 0.72 & 0.71 & 0.74 & 1.21 \\
\hline $\mathrm{Mn} / \mathrm{Ti}$ & 1.98 & 2.04 & 1.95 & 1.71 & 1.23 \\
\hline \multicolumn{6}{|c|}{ Series 2} \\
\hline Normandite & core & & & & margin \\
\hline $\mathrm{Zr} / \mathrm{Ti}$ & 2.50 & 1.88 & 0.78 & 0.31 & 0.35 \\
\hline $\mathrm{Ca} / \mathrm{Na}$ & 0.69 & 0.78 & 0.96 & 1.08 & 1.14 \\
\hline $\mathrm{Mn} / \mathrm{Ti}$ & 1.98 & 1.83 & 1.47 & 1.22 & 1.24 \\
\hline \multicolumn{6}{|c|}{ Series 3} \\
\hline Låvenite & core & & & & margin \\
\hline $\mathrm{Zr} / \mathrm{Ti}$ & 1.41 & 1.19 & 0.85 & 0.65 & 0.44 \\
\hline $\mathrm{Ca} / \mathrm{Na}$ & 0.85 & 0.85 & 0.98 & 1.02 & 1.05 \\
\hline $\mathrm{Mn} / \mathrm{Ti}$ & 1.67 & 1.61 & 1.47 & 1.38 & 1.26 \\
\hline
\end{tabular}

Chemical data acquired by energy-dispersion spectroscopy with scanning electron microscopy. 
(with scanning electron microscopy) of crystals of normandite and låvenite from Amdrup Fjord are reported. Similar patterns were found in Mont SaintHilaire normandite, suggesting similarities in the chemical processes at work in these two peralkaline environments. The above data agree with the EPMA data of Table 6, clearly showing evidence for a chemical zoning, with a "låvenitic" core gradually shifting toward a "normanditic" margin.

\section{ACKNOWLEDGEMENTS}

We benefitted from the reviews provided by M. Fleet and Yuanming Pan and the editorial comments and suggestions of R.F. Martin. P.C. Burns (University of Notre Dame) is thanked for the use of the CCD-based X-ray diffractometer. This work was supported by MURST (Ministero dell'Università e della Ricerca Scientifica) through a grant to the national project "Relations between structure and properties in minerals: analysis and applications".

\section{REFERENCES}

AnNehEd, H., FAlth, L. \& RAAde, G. (1985): The crystal structure of janhaugite, a sorosilicate of the cuspidine family. Neues Jahrb. Mineral., Monatsh., 7-18.

Chao, G.Y. \& Gault, R.A. (1997): Normandite, the Ti-analogue of låvenite from Mont Saint- Hilaire, Quebec. Can. Mineral. 35, 1035-1039.

Cromer, D.T. \& Liberman, D. (1970): Relativistic calculation of anomalous scattering factors for X rays. J. Chem. Phys. 53, 1891-1898.

\& MAnN, J.B. (1968): X-ray scattering factors computed from numerical Hartree-Fock wave functions. Acta Crystallogr. A24, 321-324.

FERGUSON, A.K. (1978): The occurrence of ramsayite, titanlåvenite and a fluorine-rich eucolite in a nepheline-syenite inclusion from Tenerife, Canary Islands. Contrib. Mineral Petrol. 66, 15-20.

Fleet, M.E. \& Pan, Yuanming (1995): The structure of $\mathrm{NaCa}_{2} \mathrm{LuSi}_{2} \mathrm{O}_{7} \mathrm{~F}_{2}$, a synthetic phase of the cuspidine group. Can. Mineral. 33, 879-884.

Johnsen, O., Grice, J.D. \& GaUlt, R.A. (1998): Kentbrooksite from the Kangerdlugssuaq intrusion, East Greenland, a new $\mathrm{Mn}-\mathrm{REE}-\mathrm{Nb}-\mathrm{F}$ end-member in a series within the eudialyte group: description and crystal structure. Eur. J. Mineral. 10, 207-219.

Khadem-Allah, B. (1993): Syénites et Pegmatites Néphéliniques du Complexe Alcalin du Tamazeght (Haut Atlas de Midelt, Maroc). Thèse de doctorat, Université PaulSabatier, Toulouse, France.
KemPE, D.R.C. \& DeER, W.A. (1970): Geological investigations in East Greenland. IX. The mineralogy of the Kangerdlugssuaq alkaline intrusion, East Greenland. Medd. Grønland 190(3).

LOUISNATHAN, S.J. \& SMITH, J.V. (1970): Crystal structure of tilleyite: refinement and coordination. Z. Kristallogr. 132, 288-306.

Megaw, H.D. (1968a): A simple theory of the off-center displacement of cations in octahedral environments. Acta Crystallogr. B24, 149-153.

(1968b): The thermal expansion of interatomic bonds, illustrated by experimental evidence from certain niobates. Acta Crystallogr. A24, 589-604.

Mellini, M. (1981): Refinement of the crystal structure of låvenite. Tschermaks Mineral. Petrogr. Mitt. 28, 99-112.

Men'shikov, Yu.P., Pakhomovskiy, Ya.A., Yakovenchuk V.N. \& BogdanovA, A.N. (1998): Normandite from the Khibiny Massif, Kola Peninsula. Zap. Vser. Mineral. Obshchest. 127(2), 86-91.

Merlino, S. \& Perchiazzi, N. (1988): Modular mineralogy in the cuspidine group of minerals. Can. Mineral. 26, 933-943.

North, A.C.T., Phillips, D.C. \& Mathews, F.S. (1968): A semi-empirical method of absorption correction. Acta Crystallogr. A24, 351-359.

O’KeEfFe, M. \& Hyde, B.G. (1978): On Si-O-Si configuration in silicates. Acta Crystallogr. B34, 27-32.

Piotrowski, A., Kahlenberg, V. \& Fischer, R.X. (1999): $\mathrm{Na}_{2} \mathrm{Ca}_{2}\left(\mathrm{P}_{2} \mathrm{O}_{7}\right) \mathrm{F}_{2}$, eine neue Verbindung mit CuspidinStruktur. Jahrestagung der DGK in Leipzig, Suppl. 16, Z. Kristallogr., 53.

SHELDRICK, G.M. (1990): Phase annealing in SHELX-90: direct methods for larger structures. Acta Crystallogr. A46, 467-473.

(1993): Program for the Refinement of Crystal Structures. University of Göttingen, Göttingen, Germany.

Smith, J.V. (1970): Physical properties of order-disorder structures with special reference to feldspar minerals. Lithos $\mathbf{3}$, 145-160.

Vlasov, K.A., ed. (1966): Geochemistry and Mineralogy of Rare Elements and Genetic Types of their Deposits. 2. Mineralogy of Rare Elements. Israel Program Sci. Translations, Jerusalem, Israel.

Received December 3, 1999, revised manuscript accepted May 12, 2000. 